\title{
CLASSIFICATION OF RICE GRAINS OF LOWLAND CULTIVARS GROWN UNDER FLOOD IRRIGATION AND SPRINKLER IRRIGATION
}

\author{
Lorenzo D. Meus ${ }^{1 *}$, Martina Muttoni², Alex C. Bartz ${ }^{2}$, Tiago A. Kaminski², Cleber M. Alberto ${ }^{2}$ \\ ${ }^{1 *}$ Corresponding author. Universidade Federal do Pampa/ Itaqui - RS, Brasil. E-mail: lorenzo_meus@ hotmail.com
}

\section{KEYWORDS}

Oryza sativa, water availability, grain quality, productivity.

\begin{abstract}
The objective of this study is to analyze the classification of rice grains of lowland cultivars grown under flood and sprinkler irrigation. The study was carried out in the agricultural years 2011/2012 and 2014/2015 using a completely randomized block design with split plots. In 2011/2012, the treatments were three lowland rice cultivars grown under flood irrigation system and five sprinkler irrigation depths with four replications. In 2014/2015, the experimental design was maintained but flood irrigation was not performed. After harvest, the samples were processed in a rice testing machine, including peeling, polishing and classification. Whole and broken grains were weighed to calculate hulling and milling yield. The classifications followed the guidelines described in Normative Instruction No. 6 of the Ministry of Agriculture, Livestock, and Supply of Brazil. In 2011/2012, there was interaction between sprinkler irrigation depths and the cultivars on hulling and milling yield, and in 2014/2015, there was significant difference in hulling yield between the cultivars. Genetic characteristics and water availability affected the classification of rice grains grown under sprinkler irrigation. In two sprinkler irrigation depths, the quality of the grains was similar to flood irrigation system. The highest milling yield was obtained in cultivar IRGA 417.
\end{abstract}

\section{INTRODUCTION}

The western border of Rio Grande do Sul state is known for the high production and processing of rice grains (IRGA, 2015). The cultivation system adopted in the region is flood irrigation, in which the water table is maintained on the soil surface for approximately $2 / 3$ of the crop cycle. Therefore, the water demand of the crops is met, but the efficiency of water use is low because of the occurrence of water loss in the irrigation channels and crops by evaporation, lateral flow, and deep percolation (SOSBAI, 2014). In these cases, sprinkler irrigation systems are used to minimize water loss.

Considering that lowland rice cultivars are adapted to flooding conditions, changes in growth, development, grain yield, and quality may change in absence of water table. The quality of the rice grains is assessed after harvest by measuring the percentage of whole and translucent grains. These values are important because they determine the commercial value of the grains (Bryant et al., 2012; Crusciol et al., 2008; Artigiani et al., 2012).

Arf et al. (2002), Singh et al. (2017), and Lee et al. (2013) observed that water restriction might affect the quality of rice grains. Therefore, changes in the type of irrigation of lowland rice cultivars may affect grain yield and quality.

The objective of this study is to evaluate the classification of grains of lowland rice cultivars grown under flood irrigation and sprinkler irrigation.

\section{MATERIAL AND METHODS}

The experiments were carried out at the Experimental Area Unit of the Federal University of Pampa (Universidade Federal do Pampa-UNIPAMPA) (latitude of $29^{\circ} 09^{\prime} 21.68^{\prime \prime} \mathrm{S}$, longitude of $56^{\circ} 33^{\prime} 02.58^{\prime \prime} \mathrm{W}$, altitude of 74 meters) in the municipality of Itaqui in the western border of Rio Grande do Sul, Brazil. According to the classification of Köppen, the climate of the region is type $\mathrm{Cfa}$ - subtropical without a defined dry season. The soil of the region was classified as Plinthudult (EMBRAPA, 2013).

The experiments were carried out in the agricultural 2011/2012 and 2014/2015 growing seasons using a completely randomized block design with split plots. In 2011/2012, the treatments included three lowland rice cultivars (INOV CL, IRGA 417, and IRGA 424), two sprinkler irrigation depths $(100 \%$ and $150 \%$ of crop

\footnotetext{
${ }^{2}$ Universidade Federal do Pampa/ Itaqui - RS, Brasil.

Received in: 8-31-2017

Accepted in: 4-24-2018
} 
evapotranspiration - ETc), one flood irrigation system, and four replications. In 2014/2015, the treatments included three lowland rice cultivars (XP 102 CL, IRGA 428, and IRGA 429), three sprinkler irrigation depths (100\%, 150\%, and $200 \%$ of ETc), and four replications.

Sowing was made in October 22, 2011, and November 17, 2014, in the recommended season for the crop in the study region. Each experimental subplot was composed of 18 rows with a length of 5 meters and spacing at $0.17 \mathrm{~m}$ between rows, totaling $15.3 \mathrm{~m}^{2}$. The sowing density was $100 \mathrm{~kg} \mathrm{ha}^{-1}$ (350 seeds per $\mathrm{m}^{-2}$ ) for cultivars IRGA 417, IRGA 424, IRGA 428, and IRGA 429 , and $50 \mathrm{~kg} \mathrm{ha}^{-1}$ (175 seeds per $\mathrm{m}^{-2}$ ) for cultivars INOV CL and XP $102 \mathrm{CL}$. The sowing density of the latter two was lower because these cultivars are hybrids.

The irrigation requirement was determined from the ETc by multiplying the reference evapotranspiration (ETo) by the crop coefficient $(\mathrm{Kc})$. ETo was estimated using the Penman-Montheith equation (Allen et al., 1998) using data on temperature, relative air humidity, wind and solar radiation obtained at the automatic meteorological station located $200 \mathrm{~m}$ away from the cultivation site. The $\mathrm{Kc}$ value was 1.05 in up to 20 days after emergence (DAE), 1.125 in $21-40$ DAE, 1.2 in $41-95$ DAE, and 0.9 in $\geq 96$ DAEs (Allen et al., 1998).

Fertilization was made according to the recommendation for rice cultivation established by the Soil Chemistry and Fertility Commission for the soils of Rio Grande do Sul and Santa Catarina (2004), with an estimated yield of $12 \mathrm{t} \mathrm{ha}^{-1}$. Weeds, insects, and diseases were managed when necessary to keep plants free of stress according to the technical recommendations for rice cultivation in the south of Brazil (SOSBAI, 2014).

The classification of grains was performed in two $0.25 \mathrm{~m}^{2}$ samples per subplot. The classified grains were dried in an oven at $60^{\circ} \mathrm{C}$ until the water humidity reached $13 \%$. After that, the samples were processed in a rice testing machine (MT, Suzukiß). At each operation, approximately $100 \mathrm{~g}$ of paddy rice were dehulled, polished and graded, and the grains remaining in the trieur (whole grains) and in the feed breaker (broken grains) were weighed to calculate the hulling yield. The classifications followed the guidelines described in the Normative Instruction No. 6 of the Ministry of Agriculture, Livestock, and Supply of Brazil (Brasil, 2009), and the percentage of grains that were broken, gritty, yellow, green and chalky, chopped and stained, moldy and bitter, and red and black ware determined. The amount of foreign matter and impurities was also calculated.

The percentage of grains with abnormalities (yellow, chopped and stained, red and black, and green and chalky) were transformed by the square root of $\mathrm{X}+0.5$. All data were subjected to analysis of variance (ANOVA) using the $\mathrm{F}$ test. The significant means were compared using the Tukey test at a level of significance of $5 \%$.

\section{RESULTS AND DISCUSSION}

The plants were subjected to different environmental conditions in the two agricultural years evaluated (Figures 1 and 2). In 2011/2012, rainfall (337.0 $\mathrm{mm})$ and the mean relative air humidity $(63.4 \%)$ were lower than those found in normal environmental conditions in the study region $(725.7 \mathrm{~mm}$ and $75.0 \%$, respectively) (Wrege et al., 2011). These conditions, together with the air temperature higher than normal $\left(26.2-24.9^{\circ} \mathrm{C}\right)$ were due to the influence of the La Niña phenomenon in this period (NOAA, 2016).

In $2014 / 2015$, rainfall $(710.0 \mathrm{~mm})$, average relative humidity $(72.1 \%)$ and temperature $\left(25.8{ }^{\circ} \mathrm{C}\right)$ were similar to the levels found in normal environmental conditions. Precipitations were common in the vegetative phase of the crop and affected grain yield, thereupon the plants at sprinkler irrigation depths $>50 \%$ of the ETc produced grains. This characteristic was different from that found in 2011/2012, which presented low pluviometric precipitation volumes, and because this only the plants grown at sprinkler irrigation depths $>100 \%$ of the ETc produced grains. 

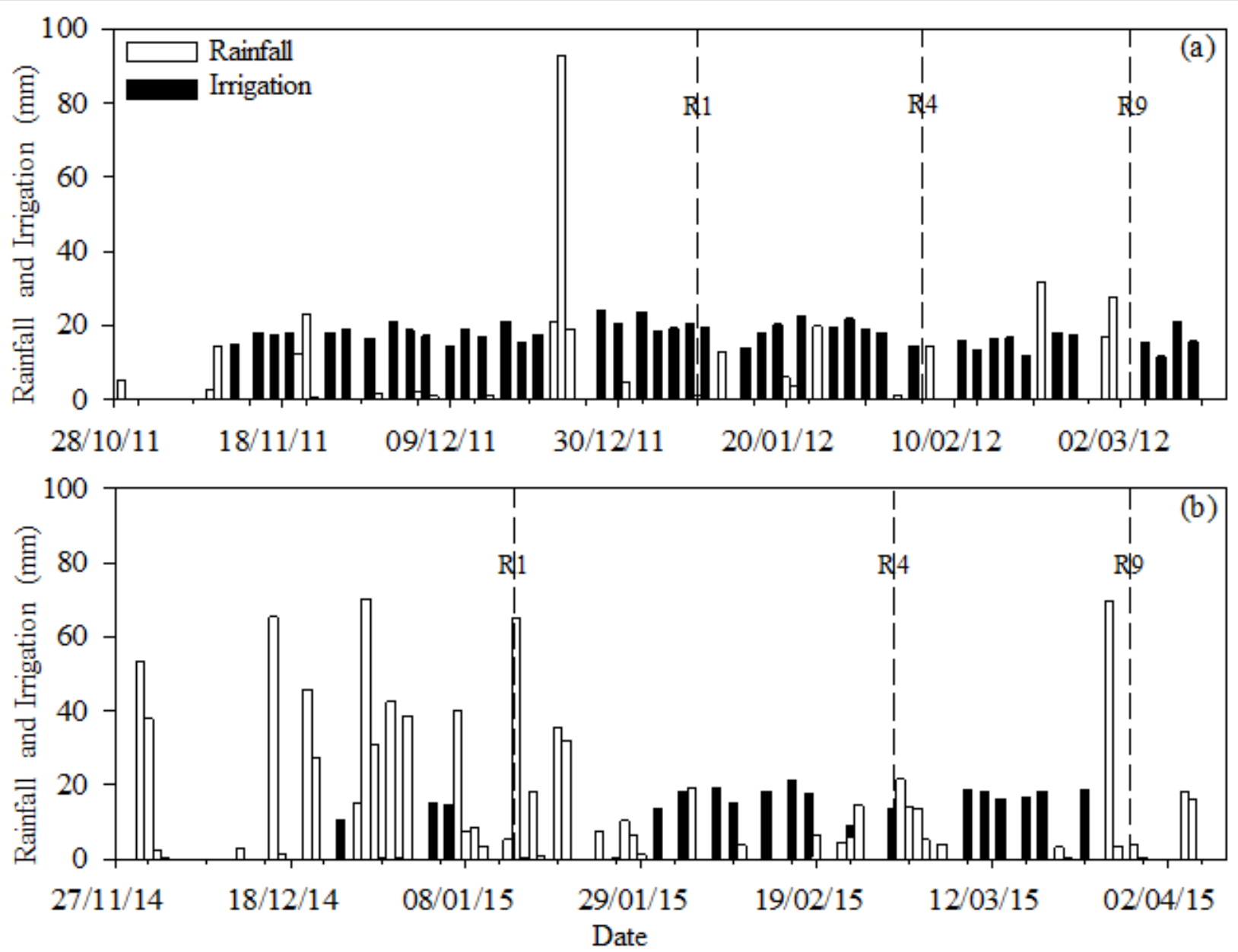

FIGURE 1. Rainfall $(\mathrm{mm})$ and irrigation $(\mathrm{mm})$ at a sprinkler irrigation depth $>100 \%$ of crop evapotranspiration during plant emergence to harvest in the agricultural years 2011/2012 (a) and 2014/2015 (b). The dashed lines represent the mean percentages in developmental stages R1, R4, and R9 using the scale of Counce et al. (2000) for lowland rice cultivars grown under sprinkler irrigation. Itaqui, Rio Grande do Sul, Brazil.

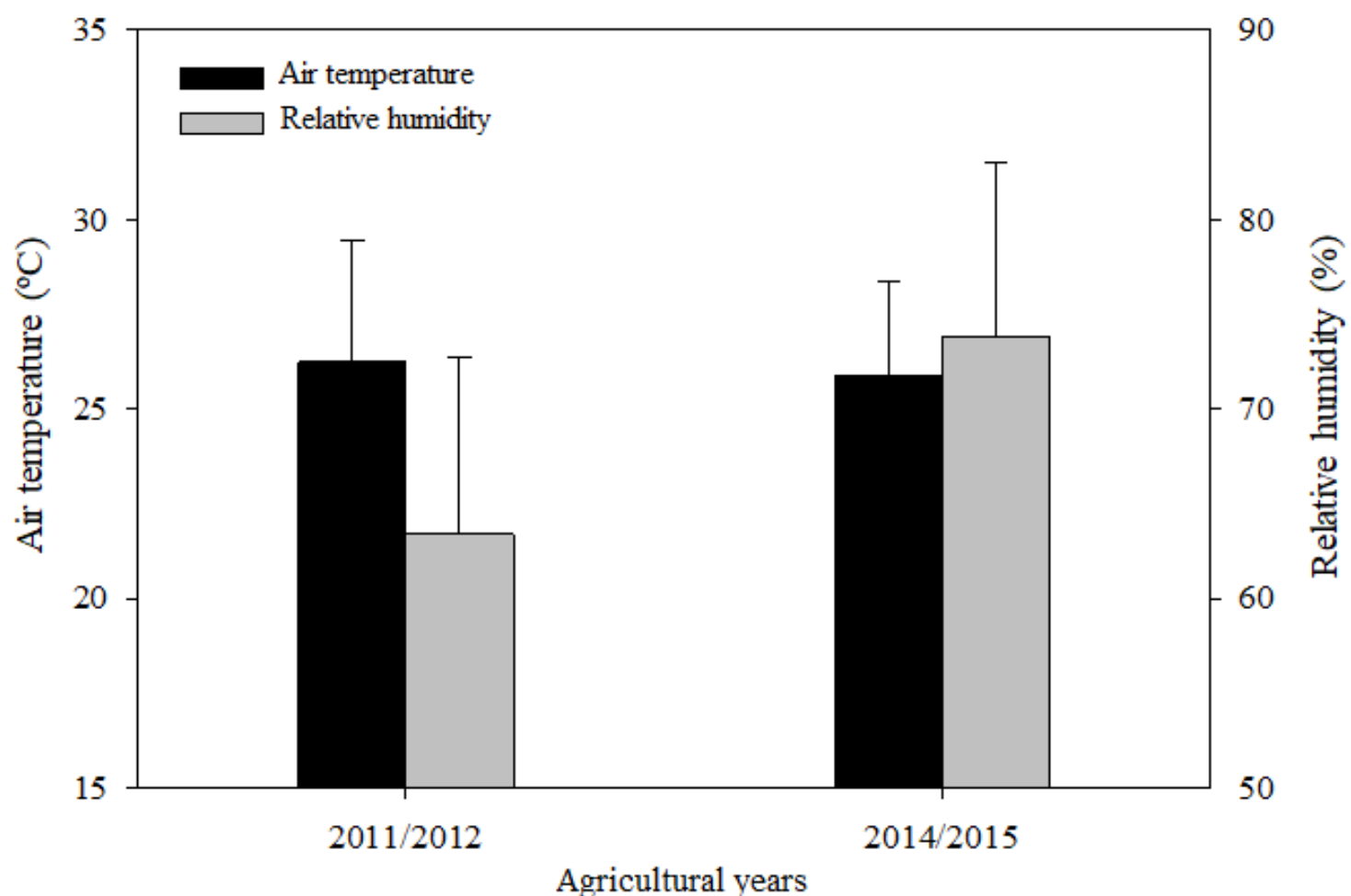

FIGURE 2. Average air temperature $\left({ }^{\circ} \mathrm{C}\right)$ and relative humidity $(\%)$ in the growing season of irrigated rice in the agricultural years 2011/2012 and 2014/2015. Itaqui, Rio Grande do Sul, Brazil. 
The effects of different sprinkler irrigation depths and rice cultivars were different between the growing seasons. In 2011/2012, the sprinkler irrigation regimes and cultivars affected the hulling and milling yield of whole and broken grains. In $2014 / 2015$, only the rice cultivars affected hulling yield. Under different sprinkler irrigation depths, the yield of different rice cultivars ranged from $64.58 \%$ to $67.77 \%$ in $2011 / 2012$ (Table 1), and mean of $70.1 \%$ in $2014 / 2015$ for cultivars and irrigation depths (Table 2).

TABLE 1. Hulling (whole and broken grains, \%) and milling yield (\%)of rice grains of lowland cultivars (IRGA 417, IRGA 424, and INOV CL) grown under two sprinkler irrigation depths (100\% and $150 \%$ of crop evapotranspiration) in the 2011/2012 growing season. Itaqui, Rio Grande do Sul, Brazil.

Sprinkler irrigation regime

$\begin{array}{llll}\text { Cultivars } & 100 \% & 150 \% & \text { Flood irrigation }\end{array}$

\begin{tabular}{|c|c|c|c|}
\hline \multicolumn{4}{|c|}{ Milling yield } \\
\hline IRGA 417 & $64,58 \mathrm{bB}$ & $67.77 \mathrm{aA}$ & $67.01 \mathrm{aA}$ \\
\hline IRGA 424 & $65.48 \mathrm{abB}$ & $66.73 \mathrm{aA}$ & $67.49 \mathrm{aA}$ \\
\hline INOV Cl & $65.69 \mathrm{aB}$ & $65.27 \mathrm{bB}$ & $66.93 \mathrm{aA}$ \\
\hline \multicolumn{4}{|c|}{ Whole grains } \\
\hline IRGA 417 & $41.30 \mathrm{aB}$ & $61.59 \mathrm{aA}$ & $63.53 \mathrm{aA}$ \\
\hline IRGA 424 & $32.20 \mathrm{bB}$ & $53.24 \mathrm{bA}$ & $55.93 \mathrm{bA}$ \\
\hline INOV Cl & $31.41 \mathrm{bC}$ & $42.81 \mathrm{cB}$ & $54.24 \mathrm{bA}$ \\
\hline \multicolumn{4}{|c|}{ Broken grains } \\
\hline IRGA 417 & $23.28 \mathrm{bA}$ & $6.18 \mathrm{cB}$ & $3.48 \mathrm{bB}$ \\
\hline IRGA 424 & $33.28 \mathrm{aA}$ & $13.49 \mathrm{bB}$ & $11.56 \mathrm{aB}$ \\
\hline INOV Cl & $34.29 \mathrm{aA}$ & $22.47 \mathrm{aB}$ & $12.69 \mathrm{aC}$ \\
\hline
\end{tabular}

*The means followed by the same lowercase letter in the column and uppercase letter in the row did not differ using the Tukey test ( $<<0.05)$.

TABLE 2. Hulling (whole and broken grains, \%) and milling yield (\%)of rice grains of lowland cultivars (IRGA 428, IRGA 429, and XP 102 CL) grown under three sprinkler irrigation dephts (100\%, 150\%, and 200\% of crop evapotranspiration) in the 2014/2015 growing season. Itaqui, Rio Grande do Sul, Brazil.

\begin{tabular}{cccc}
\hline \multirow{2}{*}{ Treatments } & \multicolumn{3}{c}{ Variables } \\
\cline { 2 - 4 } & Milling yield & Whole grains & Broken grains \\
\hline IRGA 428 & 70.54 & $65.30 \mathrm{a}$ * & $5.24 \mathrm{c}$ \\
IRGA 429 & 69.29 & $52.80 \mathrm{c}$ & $16.49 \mathrm{a}$ \\
XP 102 CL & 70.49 & $59.76 \mathrm{~b}$ & $10.72 \mathrm{~b}$ \\
Mean & 70.11 & - & - \\
\hline $100 \%$ & 70.05 & 60.78 & 9.27 \\
$150 \%$ & 69.83 & 59.30 & 10.52 \\
$200 \%$ & 70.33 & 56.82 & 13.51 \\
Mean & 70.07 & 58.97 & 11.10 \\
\hline
\end{tabular}

*The means followed by lowercase letter in the columm did not differ using the Tukey test $(\mathrm{p}<0.05)$.

In $2011 / 2012$, the cultivar IRGA 417 presented the highest percentage of whole grains (41.30-63.53\%) and the lowest percentage of broken grains (3.48-23.28\%) under all sprinkler irrigation depths (Table 1). The comparison of the irrigation systems indicated that the percentage of whole grains in cultivars IRGA 417 and IRGA 424 was statistically similar between the sprinkler irrigation depth at $150 \%$ ETc and flood irrigation.

In 2014/2015, cultivar IRGA 428 presented the highest percentage of whole grains $(65.30 \%)$ and the lowest percentage of broken grains (5.24\%) (Table 2). There was no significant difference in the percentage of whole grains between the evaluated sprinkler irrigation depths, and the mean was $58.97 \%$.

The water availability directly affected grain quality, as demonstrated by the percentages of the analyzed variables in the different growing seasons. Water is essential for grain formation because it participates in several plant mechanisms, including photosynthesis, and limited water availability may impair grain formation and the amount of photosynthates exported from the leaves (Artigiani et al., 2012).

Arf et al. (2002) evaluated upland rice cultivars grown with and without sprinkler irrigation and observed that the percentage of whole grains was increased as the volume of sprinkler water applied was increased. A similar result was found in 2011/2012 but not in 2014/2015 in our sample.

Londero et al. (2015) reported that the water deficits after anthesis did not change the quality of grains of irrigated rice. Therefore, this characteristic explains the difference between the agricultural years caused by the different distribution of rainfall, which contributed to the maintenance of grain quality regardless of the sprinkler irrigation depth adopted in 2014/2015. 
In addition, the yield potential of whole and broken grains varies according to the cultivar (Siebenmorgen et al., 2013). Therefore, the variation in the percentage of whole and broken grains between the different genotypes studied in the two agricultural years corroborates the results of Canellas et al. (1997).

Teló et al. (2011) evaluated different lowland rice cultivars and found that the percentage of whole grains ranged from $63 \%$ to $65 \%$ under ideal harvesting conditions. In our sample, the percentages of whole grains in the sprinkler irrigation depth at $150 \%$ of ETc in $2011 / 2012$ and in all sprinkler irrigation depths in 2014/2015 were similar to those found by Teló et al.
(2011) (61.59\% and 58.97\%, respectively), demonstrating that grain quality in this irrigation system was similar to that of flood irrigation.

In 2011/2012, there was interaction between the sprinkler irrigation depths and rice cultivars for the production of yellow, red and black, and green and chalky grains (Table 3). In 2014/2015, there was interaction between the sprinkler irrigation regimes and rice cultivars for the production of yellow grains (Table 4). However, red + black, chopped + stained, and green + chalky grains were not affected by the sprinkler irrigation depths and rice cultivars.

TABLE 3. Grain defects (yellow, red and black, green and chalky) of lowland rice cultivars (IRGA 417, IRGA 424, and INOV CL) grown under two sprinkler irrigation depths (100\% and $150 \%$ of crop evapotranspiration) and flood irrigation in the agricultural year 2011/2012. Itaqui, Rio Grande do Sul, Brazil.

\begin{tabular}{|c|c|c|c|}
\hline \multirow[b]{2}{*}{ Cultivars } & \multicolumn{3}{|c|}{ Sprinkler irrigation depth } \\
\hline & $100 \%$ & $150 \%$ & Flood irrigation \\
\hline \multicolumn{4}{|c|}{ Yellow } \\
\hline IRGA 417 & $0.96 \mathrm{aA}^{*}$ & $0.71 \mathrm{aB}$ & $0.74 \mathrm{aB}$ \\
\hline IRGA 424 & $0.72 \mathrm{bA}$ & $0.73 \mathrm{aA}$ & $0.72 \mathrm{aA}$ \\
\hline INOV Cl & $0.72 \mathrm{bA}$ & $0.71 \mathrm{aA}$ & $0.71 \mathrm{aA}$ \\
\hline \multicolumn{4}{|c|}{ Red + black } \\
\hline IRGA 417 & $0.71 \mathrm{aA}$ & $0.71 \mathrm{bA}$ & $0.72 \mathrm{aA}$ \\
\hline IRGA 424 & $0.71 \mathrm{aB}$ & $0.78 \mathrm{aA}$ & $0.71 \mathrm{aB}$ \\
\hline INOV Cl & $0.71 \mathrm{aA}$ & $0.71 \mathrm{aA}$ & $0.71 \mathrm{aA}$ \\
\hline \multicolumn{4}{|c|}{ Green + chalky } \\
\hline IRGA 417 & $4.21 \mathrm{bA}$ & $1.61 \mathrm{cAB}$ & $0.52 \mathrm{bB}$ \\
\hline IRGA 424 & $6.57 \mathrm{bA}$ & $4.55 \mathrm{bA}$ & $4.36 \mathrm{aA}$ \\
\hline INOV Cl & $12.11 \mathrm{aA}$ & $8.20 \mathrm{aB}$ & $1.48 \mathrm{bC}$ \\
\hline
\end{tabular}

*The means followed by the same lowercase letter in the column and uppercase letter in the row did not differ using the Tukey test $(\mathrm{p}<0.05)$.

The percentage of yellow grains of different rice cultivars ranged from $0.70 \%$ to $0.96 \%$ and $0.72 \%$ to $0.99 \%$ in 2011/2012 (Table 3) and 2014/2015 (Table 4), respectively, under different sprinkler irrigation depths.

The percentage of red + black grains ranged from $0.71 \%$ to $0.78 \%$ in 2011/2012 (Table 3). In 2014/2015, the mean percentage of red + black grains was $0.71 \%$ (Table 4). These percentages did not directly affect the treatments in question because they were related to the seed bank of red and black rice in the soil. However these percentages affect the commercialization price because the yield of whole grains is lower (Menezes et al., 1997).

TABLE 4. Grain defects (yellow, chopped and stained, green and chalky) of lowland rice cultivars (IRGA 428, IRGA 429, and INOV CL) grown under three sprinkler irrigation depths (100\%, 150\%, and 200\% of crop evapotranspiration) and flood irrigation in the agricultural year 2014/2015. Itaqui, Rio Grande do Sul, Brazil.

\begin{tabular}{cccc}
\hline & \multicolumn{3}{c}{ Sprinkler irrigation regime } \\
\cline { 2 - 4 } Cultivars & $100 \%$ & $150 \%$ & $200 \%$ \\
& & & \\
& & Yellow & $0.81 \mathrm{aA}$ \\
IRGA 428 & $0.74 \mathrm{bA} *$ & $0.72 \mathrm{bA}$ & $0.74 \mathrm{aB}$ \\
IRGA 429 & $0.99 \mathrm{aA}$ & $0.94 \mathrm{aA}$ & $0.83 \mathrm{aA}$ \\
\hline XP 102 CL & $0.78 \mathrm{bA}$ & $0.76 \mathrm{abA}$ & Green + chalky \\
\hline Treatments & & Variables & 1.62 \\
IRGA 428 & Chopped + stained & Red + black & 1.57 \\
IRGA 429 & 0.82 & 0.71 & 1.66 \\
XP 102 CL & 0.94 & 0.71 & 1.62 \\
Mean & 0.92 & 0.71 & 0.71 \\
\hline 100\% & 0.89 & 0.72 & 1.61 \\
150\% & 0.94 & 0.71 & 1.64 \\
200\% & 0.96 & 0.71 & 1.60
\end{tabular}

*The means followed by the same lowercase letter in the column and uppercase letter in the row did not differ using the Tukey test (p<0.05). 
In 2011/2012, the percentage of green + chalky grains ranged from $0.51 \%$ to $12.11 \%$, and the highest percentage was found in the INOV CL cultivar at $100 \%$ of the ETc (Table 3). The lowest percentage was found in the cultivar IRGA 417 at $200 \%$ of the ETc. In 2014/2015, the mean percentage of green + chalky grains was $1.62 \%$ (Table 4) for different rice cultivars under different sprinkler irrigation depths.

The highest percentage of chalky grains at the sprinkler irrigation regime of $100 \%$ of the ETc in $2011 / 2012$ is justified by the lower occurrence of precipitations during the grain filling period (R4-R9) (Figure 1), evidencing that this irrigation depth did not fully meet the water demand of the crops under these conditions. These results corroborate those of Arf et al. (2002), Lee et al., (2013), and Marchezan et al., (1992), whereby the percentage of chalky grains was increased with water deficit. Considering that there was a higher frequency of rainfall in the period R4-R9 in 2014/2015, there was no water restriction in the sprinkler irrigation depth at $100 \%$ of the ETc, resulting in a lower percentage of chalky grains (mean of $1.62 \%$ ) relative to 2011/2012.

Considering the percentage of green + chalky grains of the cultivars in each sprinkler irrigation depth in 2011/2012, cultivar IRGA 417 was superior to hybrid INOV CL, and this result is due to genetic characteristics of the cultivars (Marchezan et al., 1992).

The mean percentage of chopped + stained grains determined in 2014/2015 was $0.89 \%$ under flooding irrigation and $0.90 \%$ under sprinkler irrigation. This result is because of a defect in a non-metabolic process associated with the attack of paddy bugs on the grains, and pest infestation is affected by different environmental conditions (Ribeiro et al., 2012). Therefore, the analysis of the effect of the irrigation systems indicated that these two systems did not affect the percentage of chopped + stained grains.

\section{CONCLUSIONS}

The classification of lowland rice grains grown under sprinkler irrigation depths of $150 \%$ and $200 \%$ of crop evapotranspiration is similar to that of rice grown in flood irrigation system.

The cultivar IRGA 417 showed the highest yield under the sprinkler irrigation system in the agricultural year 2011/2012. In the agricultural year 2014/2015, the cultivar IRGA 428 presented the highest yield.

\section{ACKNOWLEDGMENTS}

CAPES/CNPQ, FAPERGS, and the Universidade Federal do Pampa - UNIPAMPA for providing for scientific initiation scholarships and help in publication.

\section{REFERENCES}

Allen RG, Pereira LS, Raes D, Smith M (1998) Crop evapotranspiration: guidelines for computing crop water requirements. Roma, FAO, 300p.
Arf O, Rodrigues RAF, De Sá ME, Crusciol CAC, Pereira JCR (2002) Preparo do solo, irrigação por aspersão e rendimento de engenho do arroz de terras altas. Scientia Agricola 59(2):321-326. DOI: http://dx.doi.org/10.1590/S0103-90162002000200018

Artigiani ACCA, Crusciol CAC, Arf O, Alvarez RCF, Cascente AS (2012) Produtividade e qualidade industrial de arroz de terras altas em função da disponibilidade hídrica e adubação. Pesquisa Agropecuária Tropical 42(3):340-349. DOI: http://dx.doi.org/10.1590/S198340632012000300011

Brasil (2009) Ministério da Agricultura, Pecuária e Abastecimento. Instrução Normativa ${ }^{\circ}$ 6, de 16 de fevereiro de 2009. Regulamento Técnico do Arroz. Diário Oficial [da] República Federativa do Brasil, Seção 1, 3p. Available in:

http://www.codapar.pr.gov.br/arquivos/File/pdf/ArrozInstr ucaoNormativa06_09.pdf. Accessed: Nov 17, 2014.

Bryant RJ, Anders M, Mcclung A (2012) Impact of production practices on physicochemical properties of rice grain quality. Journal of the Science of Food and Agriculture 92(3):564-569. DOI:

http://dx.doi.org/10.1002/jsfa.4608

Canellas LP, Santos GA, Marchezan E (1997) Efeito de práticas de manejo sobre o rendimento de grãos e a qualidade industrial dos grãos em arroz irrigado. Ciência Rural, Santa Maria 27(3):375-379. DOI: http://dx.doi.org/10.1590/S0103-84781997000300002

Counce PA, Keisling TC, Mitchell AJ (2000) A uniform, objective, and adaptive system for expressing rice development. Crop Science 40(2):436-443. DOI: 10.2135/cropsci2000.402436x

EMBRAPA - Empresa Brasileira de Pesquisa Agropecuária (2013) Sistema brasileiro de classificação de solos. Brasília, Embrapa, 3ed. 353p.

Crusciol CAC, Arf O, Soratto RP, Mateus GP (2008) Grain quality of upland rice cultivars in response to cropping systems in the Brazilian tropical savanna. Scientia Agricola 65(5):468-473. DOI: http://dx.doi.org/10.1590/S0103-90162008000500004

IRGA - Instituto Rio-Grandense do Arroz (2015) Produtividades municipais - safra 2014/15. Porto Alegre, IRGA. Available in:

http://www.irga.rs.gov.br/upload/20150710145210produti vidade_municipios_safra_14_15.pdf. Accessed: Mar 18, 2016.

Lee M, Kang B, Lee J, Choi W, Ko J, Choi J, An K, Know O, Park H, Shin H, Lee I, Kim J, Kim H (2013) How do extreme wet events affect rice quality in a changing climate? Agriculture, Ecosystems and Environment 171(1):47-54. DOI:

https://doi.org/10.1016/j.agee.2013.03.006

Londero GP, Marchesan E, Parisotto E, Coelho LL, Aramburu BB, Flores CS, Silva AL (2015) Qualidade industrial de grãos de arroz decorrente da supressão da irrigação e umidade de colheita. Irriga 20(3):587-601. 
Marchezan E, Dario GJA, Torres S (1992) Ocorrência de grãos gessados em três cultivares de arroz. Scientia Agrícola 49(1):87-91. DOI: http://dx.doi.org/10.1590/S0103-90161992000400012

Menezes VG, Silva PRF da, Carmona R, Rezera F, Mariot CH (1997) Interferência Do Arroz Vermelho No Rendimento De Engenho De Cultivares De Arroz Irrigado. Ciência Rural 27(1):27-30. DOI: http://dx.doi.org/10.1590/S0103-84781997000100005

NOAA - National Oceanic and Atmospheric Administration. Historical El Niño/ La Niña episodes: Cold e warm episodes by season. Available in: http://www.cpc.ncep.noaa.gov/products/analysis_monitori ng/ensostuff/ensoyears_1971-2000_climo.shtml. Accessed: Mar 05, 2016.

Ribeiro CSN, Martins GV, Guimarães JFR, Silva EF (2012) Resistência de genótipos de arroz a pragas de grãos armazenados. Revista Caatinga 25(1):183-187.

Siebenmorgen TJ, Grigg BC, Lanning SB (2013) Impacts of preharvest factors during kernel development on rice quality and functionality. Annual Review of Food Science and Technology 4(1):101-115. DOI:

http://dx.doi.org/10.1146/annurev-food-030212-18
Singh H, Buttar GS, Brar AS (2017) Crop establishment method and irrigation schedule effect on water productivity, quality, economics and energetics of aerobic direct-seeded rice (Oryza sativa L.). Paddy and Water Environment 15(1):101-119. DOI: http://dx.doi.org/10.1007/s10333-016-0532-4

SOSBAI - Sociedade Sul-Brasileira De Arroz Irrigado (2014) Arroz Irrigado: recomendações técnicas da pesquisa para o Sul do Brasil. Santa Maria, SOSBAI, 192 p.

Teló GM, Marchesan E, Ferreira RB, Lúcio A D, Sartori GMS, Cezimbra DM (2011) Qualidade de grãos de arroz irrigado colhidos com diferentes graus de umidade em função da aplicação de fungicida. Ciência Rural 41(6):960966, 2011. DOI: http://dx.doi.org/10.1590/S010384782011000600007

Wrege M.S, Steinmetz S, Reisser Júnior C, De Almeida IR (2011) Atlas climático da Região Sul do Brasil: Estados do Paraná, Santa Catarina e Rio Grande do Sul. Pelotas, Embrapa Clima Temperado; Colombo, Embrapa Florestas, $336 \mathrm{p}$. 